\title{
Introduction: Staging an Irish Enlightenment
}

\author{
David O’Shaughnessy
}

Many surveys of Enlightenment have focused on the major thinkers of the long eighteenth century, though attention has recently shifted to those accounts that emphasize the spaces and sociability of Enlightenment. ${ }^{1}$ Nonetheless, the theatre historian is likely to remain disconsolate at the elision of theatre from many of these general studies, past and present. Theatre is certainly nodded to on occasion and listed as a metropolitan space where an expanding public sphere could assimilate and practise Enlightenment, but the treatment is typically superficial. One is left with the impression that theatre functions as a largely passive space for the circulation of externally sourced Enlightenment ideas and principles, with rather less attention paid to the notion that the theatre is also an agent of Enlightenment and that the actors, playwrights, managers, and other associated people — hereafter collectively referred to as theatre practitioners - are fundamental to the generation of such ideas and principles. $^{2}$

\footnotetext{
This chapter has received funding from the European Union's 2020 research and innovation programme under the Marie Sklowdowska-Curie grant agreement No 745896.

${ }^{1}$ Ernst Cassirer, The Philosophy of the Enlightenment (Princeton University Press, 1951) and Peter Gay, The Enlightenment: An Interpretation. The Rise of Modern Paganism (London: Weidenfeld \& Nicolson, 1967). But see also, for a more recent emphasis on Enlightenment thinkers, Anthony Gottlieb, The Dream of Enlightenment: The Rise of Modern Philosophy (London: Allen Lane, 2016). For more diffused accounts of Enlightenment with emphases on its spaces and places, see, for example, Peter Clark, British Clubs and Societies 1580 1800 (Oxford University Press, 2000); Jon Mee, Conversable Worlds: Literature, Contention, and Community, 1762-1830 (Oxford University Press, 2011); Roy Porter, Enlightenment and the Creation of the Modern World (London: Allen Lane, 2000); Gillian Russell, Women, Sociability and Theatre in Georgian London (Cambridge University Press, 2007); and Chad Wellmon, Organizing Enlightenment: Information Overload and the Invention of the Modern Research University (Baltimore: Johns Hopkins University Press, 2016).

${ }^{2}$ See, for instance, Porter's Enlightenment where theatre barely registers. A glance at the index is telling: significant eighteenth-century playwrights - Goldsmith, Holcroft, Inchbald, Steele - are listed but all citations relate to non-dramatic works. The Licensing Act 1695 appears a few times but there is no mention of the 1737 Stage Licensing Act, a rather important piece of cultural legislation that would persist in one form or other until 1968.
} 
Theatre, after all, was a focal point in Georgian life. The playhouses of London and beyond were among the few spaces where people from almost all walks of life could gather together to engage with literary and performance culture. Theatre was central to political life and the display of - as well as resistance to - monarchical and aristocratical power; newspapers were heavily indebted to theatrical stories for the growth of their readership after the mid century; the parliamentary and legal worlds aped its tropes and affective strategies in the pursuit of British liberty and justice; and, it was the only literary sphere of Georgian life deemed sufficiently dangerous to be muzzled by state censorship due to its capacity to disseminate critique and channel ideas of societal change in a live participative environment. The political philosopher William Godwin, the leading reforming intellectual voice of the 1790s, believed strongly that theatre was pivotal to the mediation of Enlightenment ideas from educated persons like himself to others less well privileged: theatre formed 'the link between the literary class of mankind \& the uneducated, the bridge by which the latter may pass over into the domains of the former' ${ }^{3}$ In short, theatre was a powerful, active cultural force albeit one that has been largely sidelined in the field of Enlightenment studies. ${ }^{4}$

This volume takes the case of Ireland's theatrical exports to Britain to showcase the possibilities of using the Enlightenment framework to bring together and interrogate a substantial body of staged cultural production. ${ }^{5}$ The volume identifies London as a site of

\footnotetext{
${ }^{3}$ Bodleian Library, Oxford. Abinger MS, c. 21, ff. 57-58. The manuscript is undated but probably dates from the mid-1790s.

${ }^{4}$ It is difficult to think of any English language general survey of the Enlightenment that engages properly with the theatre. Essay collections do occasionally make an effort although they have limited scope. See, for example, E.M. Dadlez, 'The Pleasures of Tragedy' in The Oxford Handbook of British Philosophy in the Eighteenth Century, ed. James Harris (Oxford University Press, 2013), 450-67 and Peter Jones, 'Italian operas and their audiences' in The Enlightenment World, ed. Martin Fitzpatrick, Peter Jones, Christa Knellwolf and Iain McCalman (London and New York: Routledge, 2004), 323-36.

5 'Theatre is a crucial medial hinge that provides a vantage point for considering a wide array of under-analyzed cultural and social phenomena', such as, for instance, the Irish
} 
regional Irish Enlightenment activity; it treats this region as having commonalities and connections with the island of Ireland but also distinctive features; it argues that theatre has a particular force at this time for the eighteenth-century London Irish; and, that there are certain conditions of singularity that make this cultural output and its producers especially noteworthy. In brief, it suggests that the presentation of Irish civility-understood in its broadest sense as being related more to civilization than politeness — was a common desideratum of Irish theatre practitioners and one that was linked to new understandings of Irish history and culture emerging at this time.

These essays will challenge Roy Porter's view that it was not until the 1790s that Irish grievances were 'directly coloured by enlightened (by then, also revolutionary) claims'. ${ }^{6}$ Their publication is timely, coming in the wake of important reflections on Ireland and its Enlightenment, notably Michael Brown's door-stopping The Irish Enlightenment (2015). ${ }^{7}$

Moreover, it responds to recent recognition from Irish historians, both social and intellectual, to bring theatre more into this relatively new conversation. ${ }^{8}$ On the British theatre history

Enlightenment. Daniel O'Quinn and Gillian Russell, 'Introduction' in 'Georgian Theatre in an Information Age: Media, Performance, Sociability', ed. O’Quinn and Russell, special issue, Eighteenth-Century Fiction, 27.3-4 (2015): 337.

${ }^{6}$ Porter, Enlightenment Britain, 241.

${ }^{7}$ See also the various volumes in the Early Irish Fiction, c. 1680-1820 series, gen. ed. Aileen Douglas, Moyra Haslett and Ian Campbell Ross (Dublin: Four Courts Press, 2010- ); Graham Gargett and Geraldine Sheridan, eds., Ireland and the French Enlightenment, 1700-1800 (New York: St Martin's Press, 1999); Michael Griffin, Enlightenment in Ruins: The Geographies of Oliver Goldsmith (Lewisburg: Bucknell University Press, 2013); The Letters of Oliver Goldsmith, ed. Michael Griffin and David O'Shaughnessy (Cambridge University Press, 2018); Máire Kennedy, French Books in Eighteenth-Century Ireland (Oxford: Voltaire Foundation, 2001); Ian McBride, Eighteenth-Century Ireland (2009); Sean D. Moore, ed., 'Ireland and Enlightenment'. Special issue, Eighteenth-Century Studies 45.3 (2012); David O'Shaughnessy, ed., 'Networks of Aspiration: The London Irish of the Eighteenth-Century'. Special issue, Eighteenth-Century Life 39.1 (2015); and, Amy Prendergast, Literary Salons across Britain and Ireland in the Long Eighteenth Century (Basingstoke: Palgrave, 2015). ${ }^{8}$ Craig Bailey, Irish London: Middle-Class Migration in the Global Eighteenth Century (Liverpool University Press, 2013), 219 and Ian McBride, 'The Edge of Enlightenment: Ireland and Scotland in the Eighteenth Century', Modern Intellectual History 10.1 (2013): 148. 
side, while there has been a flourishing in work on the theatre in eighteenth-century studies over the past couple of decades, the considerable Irish contribution made to the Georgian theatre, pace the notable exceptions of Helen Burke and Michael Ragussis, has not been adequately considered from an ethnic perspective. ${ }^{9}$

We will begin with a brief survey of the pervasive and sustained Irish theatrical activity in Britain of the long eighteenth century; this body of empirical evidence will establish a prima facie case for a study of this cultural phenomenon. ${ }^{10}$ This essay uses the remarkably successful level of intense Irish activity in the London theatres at this time of relatively benign political conditions in London to argue that, seen in the context of patriotism and revisionist historiography, this activity can be usefully categorized as a regional strand of the Irish Enlightenment. The regional distinction is important as it allows us to connect these activities with the island of Ireland while allowing London some distinctive features and avoid any totalizing claims. The survey will be necessarily succinct and far from comprehensive but the breadth and depth of the Irish theatrical community in London — the focus of our interest—across all dimensions of the theatrical public sphere will become apparent. ${ }^{11}$ To be blunt, in this writer's experience, it is not unknown for eighteenth-

\footnotetext{
${ }^{9}$ See Michael Ragussis, Theatrical Nation: Jews and Other Outlandish Englishman in Georgian Britain (Philadelphia: University of Pennsylvania Press, 2010) and a number of essays by Helen Burke (see bibliography). The remarkable upsurge in work on Georgian theatre might be best summarized by pointing at Julia Swindells and David Taylor's excellent Oxford Handbook to the Georgian Theatre, 1737-1843 (Oxford University Press, 2014). ${ }^{10}$ Many important eighteenth-century figures will be outside the chronological remit of this volume although they certainly merit further critical attention: playwright George Farquhar (Derry; 1676/7-1707); playwright and novelist Mary Davys (Dublin?; 1674-1732); Richard Steele (Dublin; bap. 1672, d. 1729); and, actor and playwright John Leigh (Dublin?; c. 16891726?) are only some examples. Helen Burke has also shown the forceful impact of visiting Irish actors in late seventeenth-century Oxford. 'The Irish Joke, Migrant Networks, and the London Irish in the 1680s', Eighteenth-Century Life 39.1 (2015).

${ }^{11}$ The conflation of Britain with London is, of course, problematic; it is freely conceded that the interplay between metropolis and centre should receive more attention as indeed the survey of Irish theatrical migrants to follow suggests. Declan McCormack's essay is a deliberate corrective to the volume's London-centrism and shows the rich possibilities of such work. Jane Moody has also shown that regional theatre had its own distinctive rhythms
} 
century scholars to start in mild surprise when they learn that such and such a person was Irish so the exercise seems worthwhile from that perspective as well. We will come to the question of the relevance of national identity for these practitioners shortly but their previous assimilation as British or English writers has, at the very least, masked an important facet of their formative makeup. ${ }^{12}$ I also note the county of origin when known to give readers some sense of the regional geography of theatrical talent in Ireland and gesture towards potential avenues of further scholarly enquiry. ${ }^{13}$

Catherine Clive (Kilkenny; 1711-85) and Margaret Woffington (Dublin; 1720?-60) were two of the leading female actors of our period. ${ }^{14}$ Clive became the 'Darling of the Age' after being gifted the role of Polly in John Gay's The Beggar's Opera in 1732. Woffington's debut at Covent Garden was a royal command performance of Farquhar's The Recruiting Officer and made her an instant star. Both women would be at the centre of the Covent Garden and Drury Lane companies throughout the mid century. Less familiar but substantial female actors include George Anne Bellamy (Dublin; 1731?-88), who had considerable success in

and idiosyncrasies. Nonetheless, it is fair to say, I think, that London theatre generally set the tone and repertoire even if the regions mediated and responded to those plays in a distinctive fashion. Jane Moody, 'Dictating to the empire: performance and theatrical geography in eighteenth-century Britain', in The Cambridge Companion to British Theatre, 1730-1830, ed. Moody and Daniel O'Quinn (Cambridge University Press, 2007).

12 There has been some important work on 'Irishing', to use James Chandler's term, some significant figures such as Edmund Burke, Catherine Clive, Oliver Goldsmith, the Sheridan family, and Margaret Woffington. But Chandler also warns of the dangers of narrow onedimensional readings. See his discussion of Edgeworth in 'A Discipline in Shifting Perspectives: Why We Need Irish Studies’, Field Day Review 2 (2006): 30-39.

${ }^{13}$ On Irish regional theatre of the period, see Christopher Morash, A History of Irish Theatre, 1601-2000 (Cambridge University Press, 2002), 30-66.

${ }^{14}$ Much of the information that follows is readily available in various $D N B$ entries so I have eschewed footnotes. The select bibliography will contain more detailed work on individuals where appropriate. 
the 1740s and 1750s and Margaret Farren (Cork?; $d .1804$ ) who started her career in London but who flourished in York. Eliza O’Neill (Louth; 1791-1872), admired by Hazlitt and Percy Shelley amongst others, was an extraordinary and immediate success at Covent Garden, hailed as the new Siddons.

Insofar as male actors go, James Quin (London; 1693-1766), Charles Macklin (Donegal; 1697?-1799) and John Henry Johnstone (Kilkenny; 1749-1828) are likely the most well-known names. ${ }^{15}$ But we also have Spranger Barry (Dublin; bap. 1717, d. 1777) whose abilities, particularly in Shakespearean parts, made the handsome actor a bona fide star: Garrick never played Othello again after Barry's triumph in the role and their rival Romeos lit up the 1749-50 season. George Cooke (Dublin?; 1756?-1812) made his career as a provincial actor in the north of England before cracking London in 1800 with his Richard III. These names are known to theatre historians of the period but there are others, much less well known, whose very longevity demands greater famliarity. William Havard (Dublin; 1710-78), for instance, acted for over forty years in London; he was also author of the contentious tragedy Charles I which drew big crowds at Lincoln's Inn Fields in 1737 and was identified by Lord Chesterfield, in his famous condemnation of the Stage Licensing Act, as a play which should be censored. ${ }^{16}$ Alexander Pope (Cork; 1763-1835), no relation, acted at both Covent Garden and Drury Lane over five decades from 1786 to 1827 : Ireland produced not only stars but many of the supporting cast that made up the human

\footnotetext{
${ }^{15}$ Although Quin was born in London, he had considerable and heartfelt Irish roots. His grandfather was lord mayor of Dublin and his father was educated at Trinity College Dublin. Quin himself went to school in Dublin from about 1700, he may also have attended Trinity, and it was in that city he began his acting career. Quin's Irish connections are manifold and his half-brother, Thomas Grinsell, was involved in the establishment of Irish freemasonry in London in the 1750s. Laurence Dermott, Ahiman Rezon: or a help to all that are, or would be free and accepted masons, 3rd edition (London: n.p., 1778), xxxv.

${ }^{16}$ Vincent L. Liesenfeld, The Licensing Act of 1737 (Madison: University of Wisconsin Press, 1984), 83.
} 
infrastructure of the London theatrical world. ${ }^{17}$ As our knowledge of Georgian performance culture advances, we need to better assess the interactions, collaborations, and interventions of this ensemble backdrop with the Georgian stars already established in the criticism to understand how celebrity was fashioned and the repertory shaped.

Authoring plays was also an area of considerable strength. The comedies of Oliver Goldsmith (Westmeath; 1728-74), Richard Brinsley Sheridan (Dublin; 1751-1816), and 'the English Moliere', according to Hazlitt, John O'Keeffe (Dublin; 1747-1833) are regularly anthologized and staged today. But there are a host of writers of considerable achievement: Isaac Bickerstaff (Dublin; b. 1733 - d. after 1808); Arthur Murphy (Roscommon; 17271805); Hugh Kelly (Kerry; 1739-77); Elizabeth Griffith (Glamorgan; 1727-93); Frances Sheridan (Dublin; 1724-66) all achieved acclaim in the mid century period. Indeed, a gnashing William Kenrick was so incensed by seemingly endless Irish theatrical success in the 1760 s that he penned an mocking parody of Dryden's 'Epigram on Milton':

What are your Britons, Romans, Grecians,

Compar'd with thorough-bred Milesians?

Step into G--ff-n's shop, he'll tell ye

Of G--ds--th, B--k-rs--ff, and K-1l-:

Three poets of one age and nation,

Whose more than mortal reputation,

Mounting in trio to the skies,

O’er Milton's fame and Virgil's flies; ${ }^{18}$

\footnotetext{
${ }^{17}$ More could also be said about Irish musicians and singers, scenographers and prompters based in Britain.

${ }^{18}$ Kenrick, 'The Poetical Triumvirate. Written in the Year MDCCLXVII', Poems; Ludicrous, Satirical and Moral (London: Printed for J. Fletcher, [1768]), 269.
} 
Kenrick's disappointment in the wake of the failure of his own The Widowed Wife appears to have provoked this ethnic barb at Goldsmith, Bickerstaff and Kelly, all of whom were being published by the important London-based Irish publisher William Griffin. The 1770s and 1780s were also a period of remarkable Irish dominance in London's dramatic authorship: as well as Sheridan, Macklin, and O'Keeffe, it was a decade which saw considerable success for Leonard MacNally (Dublin; 1752-1820); Frederick Pilon (Cork; 1750-88); and, Robert Jephson (Dublin; 1736/7-1803). MacNally had a number of Covent Garden hits in the early 1780s. Jephson's tragedy Braganza (1775) impressed the audience so much that it 'clapped, shouted, huzzaed, cried bravo, and thundered out applause'. ${ }^{19}$ His Count of Narbonne (1781), a dramatization of Walpole's Castle of Otranto, also won much acclaim. Pilon's comedies were written rapidly to respond to the issues of the day and he had a considerable reputation on this front: 'Mr. Pilon, in [Aerostation (1784)], has seized upon the subject uppermost in the public mind, and has introduced all the collateral topics of the day'. ${ }^{20}$ One newspaper noted that Pilon and O'Keeffe received cash up front for their plays while Richard Cumberland, an eminent playwright in his own right, had to make do with the uncertainty of a benefit night (Morning Post and Daily Advertiser, 18 November 1784). Irish playwrights in the 1780s then had a certain cultural force founded on their critical and commercial success which was, in turn, a function of a more general zeitgeist of Irish success in late eighteenthcentury London.

After the turn of the century, Irish playwrights continued to offer their wares to the British public with marked appreciation. James Kenney’s (?; 1780-1849) 1803 debut Raising the Wind had thirty-eight nights in its first season at Covent Garden. James Sheridan

${ }^{19}$ Correspondence of Horace Walpole, cited in Jephson's $O D N B$ entry.

${ }^{20}$ General Evening Post, 28-30 October 1784. 
Knowles (Cork; 1784-1862) wrote a number of tragedies of sufficient quality that he was included in Hazlitt's Spirit of the Age (1825); Virginius (1820) was considered his finest achievement. No less an ambition than a desire to 'do away any lingering prejudice that may still exist in England against the people of Ireland' was the objective of The Sons of Erin, a comedy by Alicia Le Fanu (Dublin; 1753-1817) which was staged to great applause in 1812. ${ }^{21}$ Better known as a novelist today, Charles Maturin (Dublin; 1780-1824) captivated Byron with his tragedy Bertram (1816) which went through seven editions in the year after its tumultuous reception at Drury Lane. Before he became embroiled in the O'Connellite movement for Catholic Emancipation, Richard Lalor Sheil (Kilkenny; 1791-1851) wrote Evadne, or, The Statue (1819) which notched up thirty performances at Covent Garden. Although much lamented by many in the republic of letters, the Union does not appear to have impeded the persistent eastward flow of talent across the Irish Sea.

Acting and playwriting are the most public of activities associated with the theatreand are the focus of this volume - but the Irish theatrical contribution is not limited to these domains. David Taylor has reminded us that the theatre managers are all too often elided from their proper place at the forefront of theatre history and how much we have to gain from paying proper attention to these instrumental figures. ${ }^{22}$ In the Irish case, Richard Brinsley Sheridan leaps to mind, his near three decades in charge of Drury Lane Theatre constituting a substantial reign (although John Kemble did much of the day-to-day work). But Irish involvement in eighteenth-century theatre management was more extensive.

Owen Swiny (Wexford; 1676-1754) and Thomas Doggett (Dublin; c. 1670-1721) are notable figures from the early part of the century. Swiny managed the Queen's Theatre at

\footnotetext{
${ }^{21}$ Alicia Sheridan Le Fanu, The Sons of Erin, or Modern Sentiment: A Comedy, in Five Acts Performed at the Lyceum Theatre, 3rd edition (London: J. Ridgeway, 1812), 21.

${ }^{22}$ David Francis Taylor, 'Theatre Managers and Theatre History' in The Oxford Handbook of Georgian Theatre, ed. Swindells and Taylor, 70-71.
} 
Haymarket from 1706 before ending up managing Drury Lane in a consortium which included Doggett and Robert Wilks (Dublin; c. 1665-1732) in 1710. Swiny became an agent for the Italian opera in London and was based in Venice from 1721; he returned to London in the 1730s. Thomas Doggett, keen to make a public expression of his Whiggism, established a race on the Thames on 1 August 1716 to commemorate the second anniversary of George I's accession, a race that was still being run up to the end of the twentieth century. Although he did not play much active part in the management of the theatre, we should also acknowledge that Richard Steele held the governorship of Drury Lane from 1714 until his death in 1729. Macklin operated as Fleetwood's acting manager at times at Drury Lane.

But it is outside of London where Irish managers made their mark during our period. Andrew Cherry (Limerick; 1762-1812), author of The Soldier's Daughter (1804), which went through more than thirty editions in Britain and America, also managed a theatre company in Wales. Francis Aickin (Dublin; c. 1735-1812) managed the Liverpool theatre, initially with John Kemble, before then taking over at Edinburgh. The famous manager of Smock Alley Richard Daly (Westmeath; 1758-1813) cut his theatrical teeth on stage in London before turning to management back home. However, it is perhaps the name that is likely least known to theatre history that is the most striking from this list: John Boles Watson (Tipperary; 1748-1813), a friend of Roger Kemble, father of John, was a theatre manager at Cheltenham from 1779. Remarkably, Watson created a circuit of in excess of forty theatres: from Bristol it reached northwards to Holywell in Flintshire, and from Leicester it stretched across the midlands into Carmarthen in Wales. Outposts of Watson's empire could be found at Gloucester, Cirencester, Stroud, Hereford, Monmouth, Swansea, Oswestry, Evesham, Wolverhampton, Coventry, Birmingham, Daventry, Walsall, and Tamworth. 
The theatre was also central to the rapid growth of the readership of periodicals and newspapers over the century and Irish writers here made a considerable contribution to 'the thickening traffic of theatrical intelligence' between playhouses and newspapers. ${ }^{23}$ Former playwright Charles Molloy (Offaly; $d$. 1767) was editor of Common-Sense, the periodical in which the infamous Vision of the Golden Rump appeared in 1737 and helped provided the pretext for the introduction of the Stage Licensing Act. Arthur Murphy contributed dramatic criticism to the London Chronicle from 1758. William Jackson (Dublin; 1737?-95), known as Scrutineer, became editor of the Public Ledger in the mid-1770s (in whose pages he accused Samuel Foote of homosexuality), and he later acted as editor of the Morning Post 1784-86. Lapsed barrister Leonard MacNally also edited the Public Ledger for a time in the 1780s, a period in which his dramatic work was flourishing. Isaac Jackman (Dublin; 1752?1831) edited the Morning Post 1791-95) while Frederick Pilon also worked on the Morning Post when he first landed in London. A fascinating piece of research awaits to be done on ethnic and political co-operation — or collusion — between the newspapers and theatres given the number of people who had a foot in both camps; certainly, Charles Dibdin, for one, was scathing:

On the subject of theatre, indeed, [newspapers] are all agreed; actors, authors, and musician — though the first imitate, the second steal, and the third compile - are with them arrived to the highest pitch of perfection, when 'tis notorious the theatres have gradually declined for these last fifteen years. . . But the inducement is evident; and while free admission, and now and then the reception of a farce, can insure the newspapers, trash must go down; and the new school, as

${ }^{23}$ Stuart Sherman, 'Garrick Among the Media: The "Now" Performer Navigates the News', PMLA 126.4 (2011): 970. See also Lucyle Werkmeister, A Newspaper History of England 1792-1793 (Lincoln: University of Nebraska Press, 1967). 
it is called, impotent as it is, be palmed on the rising generation, as an improvement of the old one; though, Heaven knows! a spider's web may with as much propriety be instanced as an improvement on the labours of a silkworm. ${ }^{24}$

There is also a considerable body of more formal dramatic criticism. Samuel Derrick (Dublin; 1724-69) published The dramatic censor; being remarks upon the conduct, characters, and catastrophe of our most celebrated plays in $1752 .{ }^{25}$ His friend Goldsmith's Essay on Theatre (1773) was a powerful — if self-interested —indictment of sentimental comedy. Goldsmith's rival Hugh Kelly wrote an important imitation of Churchill's Rosciad in the narrative poem Thespis; or, A Critical Examination into the Merits of all the Principal Performers belonging to Drury Lane theatre (1766). Francis Gentleman (Dublin; 1728-84) provided one of the most valuable accounts of Garrick's major roles in his two-volume The Dramatic Censor (1770). Edmond Malone (Westmeath; 1741-1812) was the most important eighteenth-century editor of Shakespeare.

Our definition of those Irish impacting on the London theatre is capacious and is not limited simply to those born on the island of Ireland but extends to those who-insofar as we can tell—considered themselves to be, or were considered by others to be, Irish, and/or were deeply marked by their association with the country and its inhabitants. But as we consider this disparate group of people across the century, some questions should be posed: firstly, what difference does it make that they were Irish? How helpful is the marker of Irishness to the theatre historian attempting to recuperate the Georgian theatre scene? And is there any sense in which we can connect such a heterogeneous array of cultural producers, given their

\footnotetext{
${ }^{24}$ The Devil 1 (1786), 8-9.

${ }^{25}$ See Norma Clarke's Brothers of the Quill: Oliver Goldsmith in Grub Street (Cambridge, MA: Harvard University Press, 2016) for a fascinating account of Goldsmith's circle of Irish writers.
} 
differences across gender, religion, politics and class? The claim in these pages is that Irishness mattered a great deal to these men and women as we can observe from their patterns of sociability, so much to the fore of current eighteenth-century studies. ${ }^{26}$

Irish migrants to England, particularly London, of the period found solace, opportunity, and conviviality in networks that were sustained and strengthened by national ties. ${ }^{27}$ As a large migrant community—and one that would flit regularly between Dublin and London—such links were arguably particularly important for theatre practitioners, a means to find one's bearings within the largest city in the western world and its most celebrated theatrical scene. And there is a considerable body of anecdotal evidence that shows how established Irish actors and dramatists helped and supported new arrivals. Owen Swiny championed Woffington; Macklin helped get Spranger Barry and John Johnstone established; James Quin encouraged George Anne Bellamy and recommended Dennis Delane to Covent Garden; William Griffin gave Frederick Pilon his start at the Morning Post when he arrived in London; and Goldsmith was an obvious point of contact for Isaac Jackman when he travelled from Ireland: the accounts, letters and memoirs of actors and dramatists abound with manifold stories of interventions and encouragement.

Equally we can trace many diachronic and synchronic connections of literary influence and assistance. Goldsmith was thought to have based his lesser known play The Good Natur'd Man (1768) on an anecdote about Richard Steele being visited by the bailiffs; in turn, Dennis O'Bryen founded the plot of his comedy satirizing Charles James Fox on that

\footnotetext{
${ }^{26}$ See, for instance, Clark, British Clubs and Societies; Jon Mee, ed., 'Networks of Improvement'. Special issue, Journal for Eighteenth-Century Studies 38.4 (2015); James Kelly and Martyn Powell, eds., Clubs and Societies in Eighteenth-Century Ireland (Dublin: Four Courts, 2010); Prendergast, Literary Salons across Britain and Ireland (2015); and, Russell, Women, Sociability and the Theatre (2007).

${ }^{27}$ Craig Bailey, Irish London; Norma Clarke, Brothers of the Quill; and, David O'Shaughnessy, "Rip'ning buds in freedom's field': Staging Irish Improvement in the 1780s', Journal for Eighteenth-Century Studies, 38.4 (2015).
} 
of Goldsmith (O’Bryen's play also pays homage to Macklin's Shylock with the Irish moneylender character, Ragan), giving us a multi-generational thread to follow. ${ }^{28}$ John O'Keeffe made his start by impressing George Colman with his dramatization of the further adventures of Goldsmith's Tony Lumpkin (Tony Lumpkin in Town (1774)). He also reworked Robert Jephson's The Campaign (1784) — which featured a Stage Irishman drawn by Piloninto a triumphant two-act afterpiece Love and War (1787). Leonard MacNally dedicated his Sentimental Excursions to Windsor (1781) to Macklin and explicitly acknowledged Sir Callaghan O'Brallaghan's importance to improving the stock of the London Irish. The omnipresent Macklin also did the recently arrived O'Keeffe's prospects little harm when he declared loudly in the pit that The Agreeable Surprise (1781) was 'the best farce in the English language, except the 'Son in Law', ${ }^{29}$ Often assistance took the form of a prologue or epilogue: Pilon wrote epilogues for Macklin and he also drew a Stage Irishman for Robert Jephson's The Campaign. Malone wrote the epilogue for Jephson's The Count of Narbonne. Alicia Le Fanu drew on her brother Richard Brinsley Sheridan as Colleen Taylor discusses below. Arthur Murphy was involved in advising Macklin on early drafts. This list could be lengthened considerably although we should also note that Irish actors and writers, of course, did not depend exclusively on Irish connections, friendships and patronage for support: figures such as Samuel Johnson, David Garrick and Thomas Harris were evidently of significant importance for many. But we can confidently say that Irish aid was generous and forthcoming particularly at the outset of careers — at that moment when it was most neededand it tended to be sustained over longer periods. Irish actors and writers looked to their own

\footnotetext{
${ }^{28}$ See David O'Shaughnessy, 'Making a play for patronage: Dennis O'Bryen's A Friend in Need is a Friend Indeed (1783)', Eighteenth-Century Life 39.1 (2015).

${ }^{29}$ Recollections of the life of John O'Keeffe, written by himself, 2 vols. (London: Henry Colburne, 1826), 2: 5.
} 
for help, inspiration and that all-important 'in' when they attempted to forge a career in London.

One must be careful to avoid suggesting that a shared Irishness collapsed important distinctions within this rather heterogeneous group. And, although the overwhelming impression of conviviality and support is convincing, there are well documented cases of antagonism (e.g. Quin and Macklin; Woffington and Clive; Goldsmith and Kelly). Nonetheless, the essays in this volume collectively make the argument that all of this cultural activity, despite differences in politics, religion, gender, class or otherwise, all contributed to an important strand of the Irish Enlightenment.

\section{3.}

It is probably safe to say now that the breezy sidelining of the notion of an Irish Enlightenment is now well and truly in the past; however, questions as to its extent and nature remain excitingly open. ${ }^{30}$ While there have been many noteworthy contributors to the discussion, Michael Brown's The Irish Enlightenment is the most thorough and ambitious to date. Brown's Irish Enlightenment unfolds over three thematic periods: a religious Enlightenment (1688- ca.1730), a social Enlightenment (ca. $1730-c a .1760)$, and a political Enlightenment (ca. 1760-98). A much simplified version of Brown's argument is that the initial stages of the Irish Enlightenment are characterized by the confessional divide between Catholics, Anglicans and Presbyterians and their respective modes of thought, scholasticism,

\footnotetext{
${ }^{30}$ Roy Porter and Mikuláš Teich's The Enlightenment in national context (Cambridge University Press, 1981) did not include an essay on Ireland although the names of Burke, Steele, Toland, and Swift are all co-opted in the English Enlightenment. See also Enlightenment in Britain, xviii-xix for a flimsy conflation of the Irish in Britain with the 'English' (although Porter does make clear that his discussion is focused on the island of Britain).
} 
empiricism, and rationalism; the middle stage sees those divisions recede as a result of the convivial sociability of the burgeoning public sphere; while the conflict between empiricist loyalism and rationalist republicanism finally collapses around the acrimonious nationalist question of 'who is Irish?', thus bringing about rancour, rebellion and the end of the Irish Enlightenment.

While one can acknowledge the impressive scope of The Irish Enlightenment, like many general surveys noted at the outset of this introduction, it has a theatre problem. Brown, to his credit, includes Goldsmith's She Stoops to Conquer (1773 and Macklin's Love à la Mode (1759) in his wide-ranging discussion of the sociable Enlightenment but the plays are decontextualized, both from the authors' respective bodies of work and from their performance history and reception. Brown also identifies the theatre as a 'barometer' for the sociable Enlightenment rather than considering it a catalyst for Enlightenment ideas. ${ }^{31}$ There is a further geographical issue: the discussion co-opts these plays into a framework of the Irish Enlightenment, one concentrated on the island of Ireland, while leaving aside the fact that both plays were first staged in London and both men were, at the moments of these performances, long-term residents of London. Macklin moved there sometime in the mid1720s and Goldsmith never once returned to Ireland after he arrived there in 1756. Certainly, the comedies were also staged at Dublin theatres but these are substantive lacunae in his discussion insofar as the theatre historian might be concerned. As we know, Macklin's plays had very different receptions in Dublin and London so the borders of Brown's Enlightenment, notionally the island of Ireland, are rather more porous than they seem to be

${ }^{31}$ Brown, Irish Enlightenment, 241. 
presented..$^{32}$ And as we have seen from our survey, mobility of people is an essential component of our object of study.

There will be no advocacy for a hard border around the Irish Enlightenment here; rather, this volume will settle for the more modest assertion that Irish theatre practitioners in London consist of a distinctive and important facet of a broader and more diffuse Irish Enlightenment, one that is energized by its transnational kinesis and the cosmopolitan environs of London and epitomized by O'Keeffe's ebullient recollection of arriving in London:

Oh joys of youth! from sight to sight I flew,

Now topp'd the Monument, now mounted St Paul's,

No house five minutes kept me in its walls;

My bunch of flowers held not one sprig of rue,

The wax-work, Tower, and Abbey tombstones, all are $n e w^{33}$

The energizing effect of O'Keeffe's move to London makes clear the problem identified by Charles W. J. Withers of seeing the nation as a 'container' for the Enlightenment. When it comes to the theatre and the extraordinary and enriching free movement of labour, capital and entrepreneurial creativity between Irish and British theatres, particularly between Dublin and London, it is surely impossible to do so. Withers's suggestion that we might rather consider 'regional manifestations' of Enlightenment ideas is a helpful way of considering the particularities of the voluminous Irish theatrical activity in the context of London's vibrant

\footnotetext{
32 On the varied reception of Macklin's plays, see Paul Goring “"John Bull, pit, box, and gallery, said No": Charles Macklin and the limits of ethnic resistance on the eighteenthcentury London stage, Representations 79.1 (2002).

${ }^{33}$ Recollections of John O'Keeffe, 1:74.
} 
metropolitan environs: London is an important region of Irish Enlightenment but not one with a rigidly hermetic border. ${ }^{34}$ Mobility between Ireland and England was crucial for the development of Irish theatre practitioners and equally to the richness of London theatres; mobility is also critical to our understanding of the Enlightenment; and one might well say that it is fundamental to its spirit. Withers argues for the importance of showing how, where and the form in which ideas moved: 'translation', 'appropriation, 'reception', and 'mediation' are all key terms for explaining the Enlightenment, rather than simply describing it. ${ }^{35}$

Mediation is also the central term in the recent influential collection This is Enlightenment. For its editors, the Enlightenment is an event in the history of mediation in which 'print took center stage' ${ }^{36}$ One does not have to dispute this claim to be discomfited by the near absence of theatre from the volume as a whole,${ }^{37}$ particularly when the production of plays in the period involved such a complex and scrutinized flow of mediations, from author(s) to theatre manager to copyist to Examiner of lays to prompter to actors to audience, not to mention the 'complex intermedial relations endemic to theatrical culture' postperformance, ${ }^{38}$ that is, the centrality of theatre to newspapers (whose Enlightenment credentials seem beyond reproach), caricature, painting, and the novel, for instance. Theatre equally 'insinuat[ed] itself into other forms of mediation' just as print does. ${ }^{39}$ Given the proliferation of Irish theatre practitioners, we might proffer the Irish theatrical production of the period as, to take another Siskin and Warner term, a cardinal mediation, one that is not

\footnotetext{
${ }^{34}$ Charles W. J. Withers, Placing the Enlightenment: Thinking Geographically about the Age of Reason (University of Chicago Press, 2007), 41.

${ }^{35}$ Ibid, 61.

${ }^{36}$ Clifford Siskin and William Warner, 'This is Enlightenment: An Invitation in the Form of an Argument' in This is Enlightenment (University of Chicago Press, 2012), 10.

${ }^{37}$ Michael McKeon's essay 'Mediation as Primal Word: The Arts, the Sciences, and the Origins of the Aesthetic' is an honourable exception.

38 'Introduction' to Georgian Theatre in an Information Age, O'Quinn and Russell, 337. See also O'Quinn's, Entertaining Crisis in the Atlantic Imperium, 1770-1790 (Baltimore: Johns Hopkins University Press, 2011).

${ }^{39}$ This is Enlightenment, 10.
} 
necessarily 'better' but one that is enabling — due to its multiplicity—in 'particular times and particular places'. ${ }^{40}$

London offered a receptive environment during our period: broad political conditions such as Scottophobia post 1745 and again during Bute's brief premiership in the early $1760 \mathrm{~s}^{41}$; increased reliance on Irish troops during the Seven Years' War, ${ }^{42}$ increased visibility of elite and articulate Irish (such as Burke and Goldsmith being members of Johnson's Club); increasing Irish activity in middle-class professions in London ${ }^{43}$ helped create an environment more receptive to the prominent actors and playwrights of the mid eighteenth century. All of these conditions facilitated - to maintain our Siskin and Warner frameworkthe upward trajectory of Irish participation in the new theatrical infrastructure (gradual expansion of playhouses over the century); the new genres and formats of theatre, print and speech; new associational practices; and the new protocols of theatre (such as statutory censorship, introduced in 1737). The critical mass of Irish participants could flourish in the years subsequent to 1740 .

What then might be the distinctive feature of the London Irish theatrical Enlightenment? As Dan Edelstein has pointed out, 'To locate the singularity of the Enlightenment, we must also consider what was mediated, not just how it was'. ${ }^{44}$ The ideas, not just the means of transmission and modes of reception, matter. Edelstein champions a

\footnotetext{
${ }^{40}$ Siskin and Warner, 'This is Enlightenment', 11.

${ }^{41}$ See John Brewer, 'The Misfortunes of Lord Bute', The Historical Journal 16.1 (1973). The anti-Caledonian mood in London was noted by activists such as Charles O'Conor of the Catholic Committee who wrote opinion pieces for the London newspapers, often to compare the loyalism of Scottish Presbyterianism unfavourably with that of Irish Catholicism. See David O'Shaughnessy, "Bit, by some mad whig": Charles Macklin and the theater of Irish Enlightenment', Huntington Library Quarterly, 80.4 (2017): 568-69.

${ }^{42}$ Stephen Conway, War, State, and Society in Mid-Eighteenth-Century Britain and Ireland (Oxford, 2006), 57-66; Thomas Bartlett, The Fall and Rise of the Irish Nation (Dublin, 1992), 57-58.

${ }^{43}$ See the various essays in O'Shaughnessy, Networks of Aspiration.

${ }^{44}$ Dan Edelstein, The Enlightenment: A Genealogy (University of Chicago Press, 2010), 11.
} 
'thin coherence' among Enlightenment thinkers and movements, rather than 'shattering [it] into a thousand little parts' as a pragmatic way of holding together a shared idea of Enlightenment. ${ }^{45}$ This is helpful in terms of thinking about the commonalities and differences between this regional activity and Ireland; my suggestion is that the term 'civility' has a broad coherence for the London Irish theatrical Enlightenment and that of the home nation but that there was a slightly more urgent register and emphasis for the London Irish, located as they were at the epicentre of mediating the Irish nation and people to their political masters.

Civility is also a central idea for Michael Brown's sociable Enlightenment:

Civility offered a broad diagnosis of the ailments of the country and a means to ameliorate its condition, providing a varied and interlocking vocabulary for articulating the dilemmas of Irish life....forged a bond between private virtues and public benefits.....civility supplied the Irish Enlightenment with a discourse for discussion and a project of acidity that crossed the confessional divides....enabled Presbyterians, Protestants, and Catholics to combine creatively in the development of their society....It provided a discursive mode in which those committed to rational and empirical methodologies could collaborate in ameliorating the social environment. ${ }^{46}$

But for those Irish in London, on display to the English on and off stage, civility might be thought of as being not only to do with polite conduct, improvement and so on but also as being more specifically associated with the idea of civilization itself. London, the ultimate

\footnotetext{
${ }^{45}$ Ibid., 13-14.

${ }^{46}$ Brown, Irish Enlightenment, 209
} 
jurisdiction of political power for Ireland, was the frontline for the practical performance of civilization, essential to the Irish patriot movement. The question of Irish civility in this sense had been much in question - if not outright dismissed - in the wake of 1641 and reports of Irish barbarism and savagery. Theatre and its writers and performers offered a very public and potent stage for the Irish to demonstrate their capacity for civility in this sense. Like Godwin, Irish dramatists saw theatre as offering a bridge to political justice; in the Irish case this bridge involved shifting English perceptions of Ireland from barbarism to civilization. Certainly, attitudes towards the Irish in London were often uncivil right through the century and the theatre was also at times a rather raucous space to present civility but, collectively, through their command of dramatic genres, technical craft, behaviour on and off stage, andcrucially — their mediated selves across the mediascape of Georgian Britain, they could present a highly visible and cultured counter-narrative to centuries of historiographically rooted prejudice. And if we agree that the event of Enlightenment must involve a principle of singularity, our period of intense theatrical activity coincided with an enabling historiographical counter-narrative that validated the notion of Irish civilization; this 'new' historiography was a response to the 1720 Declaratory Act which reaffirmed Westminster's right to legislate for Ireland. As this is a book about theatre, we shall attempt to unpack all of this and to move towards a conclusion by considering a performance event. Thus, with an ostentatious precision worthy of Archbishop Ussher himself, let us nominate 9pm-ish on Saturday 14 February 1741 as the date of a performance singularity through which we can tie together the complex intermediation of patriotism, historiography, and performance as they coalesce around the London Irish theatrical Enlightenment. 
There was an expectant audience in attendance that night at Drury Lane Theatre. It was to be the first performance of Shakespeare's The Merchant of Venice in over forty years while George Granville's adaptation The Jew of Venice (1701), believed to have improved Shakespeare, had held the stage. Charles Fleetwood, then manager, was not enthusiastic, seeing little potential for the sort of financial success he required to fund his gambling habit. But Macklin, then acting manager of the theatre, persisted and took the role of Shylock with the intention of playing it seriously despite strong scepticism: 'the laugh was universal.- - His best friends shook their heads at the attempt; whilst his rivals chuckled in secret, and flattered him with ideas of success, the surer to work out his destruction' ${ }^{47}$ The performance, as we know, was an enormous success with Macklin receiving all sorts of rapturous plaudits from audience, colleagues and manager on the night. ${ }^{48}$ The claim to Irish Enlightenment may seem strained at this point: as Emily Anderson has shown, Macklin's performance seems to have confirmed negative perceptions of his personal public character. ${ }^{49}$ Indeed, far from Enlightenment, Macklin's snarling and vicious Shylock seems likelier to have re-invoked graphic descriptions of the cruel sectarian violence supposedly meted out by Irish Catholics in 1641. Yet there are two central components to Macklin's approach to Shylock that we might consider in order to offer an alternative view: the shift to a naturalist style of acting and the historical research that underpinned his interpretation of the character. Let us take each of those in turn as we focus more on Macklin the man, rather than the actor.

Paddy Bullard has shown how the Irish understanding of rhetoric differed significantly from that of the English, suspicious of its potential for duplicity. Irish thinkers, such as Robert Molesworth, Samuel Madden and John Toland, saw rhetoric as an essential component of a civic education that would empower the patriot Irish to advocate for civil and

\footnotetext{
${ }^{47}$ George Cooke, Memoirs of Macklin, 91.

${ }^{48}$ For a full account see Cooke, 92-95 and Appleton, 47-55.

${ }^{49}$ Emily Anderson, 'Celebrity Shylock', PMLA 126.4 (2011): 941-42.
} 
economic rights. While this resulted in important publications on eloquence and oratory in the 1750s by academics John Lawson and Thomas Leland, not to mention actor-manager Thomas Sheridan, Bullard dates its roots to Molesworth in the 1690s and points to considerable discussion in the 1720s: it is a foundational precept of Irish patriotism. ${ }^{50}$ Molesworth, like many of the eighteenth-century dramatists discussed above, was educated at Trinity College Dublin and Kirkman's account of Macklin's time at Trinity (as a servant) circa the same period suggests this is where Macklin's desire for self-improvement began. ${ }^{51}$ It is probably here that he first encountered formal ideas of Irish patriotism. Macklin's later patriot credentials are certainly robust and his innovative natural style of acting, which offered the audience the sense of seeing the psychological truth of a character through the natural and affective delivery of his lines, might be read as emerging with—and emanating from - the Irish patriot emphasis on eloquence. ${ }^{52}$ People, as Siskin and Warner have argued, have always required 'tools' for mediation; acting, where bodies are tools for the communication of refined or heightened emotions and ideals, is a particularly potent mode of mediation. ${ }^{53}$ Macklin's triumphant radical reorientation of his embodied self opens up new possibilities and channels of dissemination and representation of Irish character, culture and history. The naturalistic mode, embodied in an Irish actor, challenged established perceptions of the Irish and facilitated the shift in the Stage Irishman from the devious Teague O'Divellys of the early century to the natural sincerity of Sir Callaghan O'Brallaghan and Major O'Flaherty of the later period. Even if Macklin's representation of Shylock evoked malevolence and fear in the moment, the public display of his capacity to mediate Shakespeare, to embody ethnic character in a newly 'real' way, and display command of

\footnotetext{
${ }^{50}$ Paddy Bullard, Edmund Burke and the Art of Rhetoric (Cambridge University Press, 2011), 52-78. See also Brown, The Irish Enlightenment, 171-76.

${ }^{51}$ Kirkman, Macklin, 1: 44-45.

${ }^{52}$ On Macklin's Irish patriotism, see O'Shaughnessy, 'Bit, by some mad whig'.

${ }^{53}$ Siskin and Warner, 'This is Enlightenment', 4-5.
} 
rhetorical eloquence — not to mention his restoration of Shakespeare's text to the stagegenerated new possibilities of mediation. His appropriation and powerful re-engineering of Shakespeare —we might also consider Love à la Mode in this way-demonstrates the Irish capacity to assimilate 'high' British culture and re-imagine it in a way that underlined the value of cultural syncretism. John Hill, in the first serious British acting treatise to emphasize the emotional range of an actor, identified Macklin as a pioneering actor of the 'superior class' who could actually improve upon the authorial text:

The author whose piece is to have the principal characters play'd by persons of this class may always attempt to venture to omit things, or to express himself imperfectly ... since he will be sure to have a supplement or a commentary as far as the nature of the passage will bear it in the performing. ${ }^{54}$

Hill recognised that Macklin's acting was an act of reading with intellectual and political implications. Macklin's eloquence and acting style provided an important supplement, one that publically transmitted his own intellectual accomplishments. And, at this time, in 1741, Macklin can be located within a critical mass of celebrated Irish acting. Margaret Woffington and Catherine Clive were also powerful agents for Irish theatrical prowess. ${ }^{55}$ As for James Quin, although his classical style is understood as being eclipsed by Macklin, the evidence does not support this conclusion. Macklin and Quin played different roles in different styles but were both successful. ${ }^{56} \mathrm{We}$ might be better served by thinking of the quartet of Clive, Macklin, Quin and Woffington as representing the increasingly widening rhetorical range of

\footnotetext{
${ }^{54}$ John Hill, The Actor, 249.

${ }^{55}$ Felicity Nussbaum, Rival Queens: Actresses, Performance, and the Eighteenth-Century British Theater (Philadelphia: University of Pennsylvania Press, 2010), 182-88, 190-224. ${ }^{56}$ See my discussion of Quin's Cato below, XX-XX, and Figure 1.9 showing the 'league tables' of London acting, XX.
} 
Irish acting, capable of confidently coding Irish civility for English audiences in a multiplicity of ways. For the eighteenth-century Irish actor, mastering verse or comic dialogue with eloquence and verve, coupled with innovative acting methods, the initial claim to Enlightenment was often simply the displayed act of performance itself.

Macklin's public success opened doors to participation in the sociable Enlightenment:

A few days afterwards, Macklin received an invitation from Lord Bolingbroke to dine with him at Battersea. He attended the rendezvous, and there found Pope, and a select party, who complimented him very highly on the part of Shylock, and questioned him about many little particulars relative to his getting up the play, \&c. Pope particularly asked him, why he wore a red hat? and he answered, because he had read that Jews in Italy, particularly in Venice, wore hats of that colour. "And pray, Mr. Macklin,” said Pope, "do players in general take such pains?" - "I do not know, Sir, that they do; but as I had staked my reputation on the character, I was determined to spare no trouble in getting at the best information." Pope nodded, and said, "it was very laudable." 57

Macklin's triumph in this particular role mediated his access to social circles previously out of reach but this anecdote suggests that it was not only his delivery that facilitated his success but that his performance was grounded in cognitive reflection that dared to know. The supplement he added to the Shakespearean text was historiographically founded. Macklin's success was based on his careful reading of his 'much-thumbed', as biographer Appleton claims, copy of Josephus' History of the Jews. ${ }^{58}$ The sale catalogue of Macklin's library

${ }^{57}$ Cooke, $94-95$.

${ }^{58}$ Appleton, 46. 
reveals a long-lasting interest in history and he went on to write a history play-dicussed in my chapter below_as well as deliver lectures on British and Irish history at the British Inquisition. ${ }^{59}$ Historiography was also central to Irish patriotism in the period as the Irish began to offer a counter-narrative to prejudice exemplified by John Temple's History of the Irish Rebellion (1646), reprinted frequently during the eighteenth century. ${ }^{60}$

When the Declaratory Act was debated in 1720, Richard Steele MP spoke against the bill. According to one report, he concluded by addressing the preamble to the bill and 'shew'd the severity of laying a whole Nation under the Imputation of attempting to Rebel; when nothing possibly could be shewn of that kind; but on the contrary, Numberless Instances might be given of their unparallel'd Zeal for the present Government, one of which he wou'd mention, Namely, the putting a price on the Pretenders Head, at a time when the People of England dar'd not do it'. ${ }^{61}$ We can readily infer that the preamble raised the spectre of Ulster's bloody rebellion of 1641 but rehashing ideas of Irish Catholic barbarity, incivility, and inability to self-govern would only galvanize Irish indignation. ${ }^{62}$ Swift's Irish pamphlets of the 1720s, of course, are central here but there was also an important London response with the publication of the English translation of Geoffrey Keating's Foras Feasa ar Éirinn

\footnotetext{
59 Thomas King, A Catalogue of the Library of the Late Mr. Charles Macklin, Deceased [London, 1797]. The sale catalogue has now been digitised by Paul Goring and Rebecca Vollan and is searchable. https:/www.librarything.com/profile/CharlesMacklin ${ }^{60}$ See Clare O'Halloran, Golden Ages and Barbarous Nations: Antiquarian Debate and Cultural Politics in Ireland, c.1750-1800 (Notre Dame and Cork: University of Notre Dame Press and Cork University Press, 2004) for a comprehensive discussion of the new Irish historiography of the period although the focus is very much on Ireland.

${ }^{61}$ Several Speeches in the House of Commons in England, For and against the BILL for the better securing the Dependency of the Kingdom of Ireland, on the Crown of Gr. Britain. In a Letter from a Gentleman there to his Friend here. (Dublin, n.p., 1720), 5-6.

${ }^{62}$ See Joep Leerssen, Mere Irish and Fior Ghael: Studies in the Idea of Irish Nationality, its Development and Literary Expression Prior to the Nineteenth Century (Notre Dame and Cork: Cork University Press and Field Day, 1986); and, David Hayton, 'From Barbarian to Burlesque: English Images of the Irish c. 1660-1750', Irish Economic and Social History 15 (1988), 5-31.
} 
published in 1723 in London. ${ }^{63}$ Keating's history was described in the first Dictionary of National Biography as 'probably the last book of importance to circulate in manuscript in the British Isles' but the complicated and controversial story of its translation and publication need not detain us here. ${ }^{64}$ Keating's fiery preface took British historians to task for acting like dungbeetles who have 'ignored the 'sweet Blossoms' and 'fragrant Flowers' of Irish cultural history and instead 'directed by [their] sordid Inclination, [they] settle[d] [themselves] on some nauseous Excrement'. Keating's book, a complex mix of fact and fabulous fiction, offers a radically different account of the rich culture and traditions of Gaelic Ireland as well as tracing the genealogy of the nation back to Japhet, son of Noah, disputing the idea of the ‘wild Irish' emerging quasi-organically from a bog, and its lengthy and eminent subscriber list indicates a London readership receptive to new ideas of Irish civility. ${ }^{65}$ Later in the century Charles O'Conor developed Keating's thinking for a post-Humean historiography in ways that were fundamental for the mediation of Irish civility to London and impressed, among others, Samuel Johnson. ${ }^{66}$ For both Keating and O'Conor, the reclamation and validation of Gaelic culture - language, music, writing — were central to their argument.

The historical turn of 1720s Irish patriotism understood that empirical evidence needed to be mediated through persuasive channels to shift the public mood; the presentation of Irish civility and culture was central to claims for political agency, and theatre practitioners in London were engaged with its mediation. John Quin was a subscriber to Hugh McCurtin's

\footnotetext{
${ }^{63}$ Geoffrey Keating, The General History of Ireland...C Collected by the Learned Jeoffrey Keating, D.D., trans. and ed. Dermod O'Connor (London: Printed by J. Bettenham, 1723). ${ }^{64}$ Diarmuid Ó Catháin, 'Dermot O'Connor, translator of Keating' Eighteenth-Century Ireland / Iris an Dá Chultúr 2 (1987), 67-87.

${ }^{65}$ Subscribers who paid the 2 guinea cost of the book included the Prince of Wales, the archbishops of Canterbury and York, the Bodleian Library, the master of the Charter House school, Richard Steele, Hans Sloan, various members of the Irish and English peerage, and many of the London Irish diaspora, including names with patriot resonance such as Molyneux, Philpot, and O'Conor.

${ }^{66}$ See Thomas M. Curley, Samuel Johnson, the Ossian Fraud, and the Celtic Revival in Great Britain and Ireland (Cambridge University Press, 2014), especially chapters 4 and 5.
} 
A Brief Discourse in Vindication of the antiquity of Ireland... (1717), essentially an early and abridged translation of Keating published in Dublin. Macklin's library contained works by Toland, O'Conor and others on Irish history and culture and his Love à la Mode makes specific reference to the importance of history-writing to national narratives. Catherine Clive's The Faithful Irishwoman (1765) was boldly confident in Mrs OConner's claims that they spoke better English in Ireland. Leonard MacNally's The Claims of Ireland (1782) seeks to legitimate Irish language and music, linking them to his appeal for Irish political autonomy; the pamphlet also point to the great similarities between Britain and Ireland and his play Robin Hood (1784) makes gestures towards cultural syncretism, the plot combining the English legend with Goldsmith's 'Edwin and Angelina' and with the music drawn from 'English and Irish ballads' ${ }^{67}$ The new historiography of Ireland had a galvanizing influence on Irish theatre practitioners in London as they mediated their history, culture and national character to the London audiences.

5.

The essays in this volume vary in their approaches to the Irish Enlightenment. But Macklinappropriately, given the longevity of his London tenure-is a unifying presence for them all. His career and life touched on those of every significant person of interest in the essays which follow. But when we reflect on how an Irish-speaking Catholic from the very rural Inisowen peninsula of Donegal, on the north-west coast of Ireland, travelled initially to Dublin, where he worked as a badge-man, or servant, at Trinity College Dublin, before overcoming initial racial prejudice in London and a criminal conviction, to deliver one of the great Shakespearean performances of the century on 14 February 1741 and then writing one

${ }^{67}$ St. James 's Chronicle, 17 April 1784. 
of the boldest political plays of the century, it is difficult think of anyone-within the theatre or without — who might be better thought to embody the Enlightenment values of mobility, self-improvement and the public performance of 'daring to know'. Add to the mix his advocacy for actors' legal rights, his frequent brushes with the Examiner of Plays, his attempt to include women in his British Inquisition project, and his emboldened speaking of the Irish language to the nonplussed Samuel Johnson, we can readily observe that Enlightenment values of equality, the challenging of institutional authority, respect across genders, and advocacy for minority cultures emerge through his extraordinary — and extraordinarily long — career.

Macklin was certainly a combative figure but the rude Macklin left to us in some accounts is, I think, largely irrelevant: what is essential here is what he meant to those Irish that looked to him as a talisman of Irish success and improvement. In any case, his truculence has often been overstated and thus unfairly diminished his Enlightenment credentials. ${ }^{68}$ Macklin is metonymic of a regional London Irish theatrical Enlightenment that was unified by a common objective of producing a counter-narrative of Irish civility to centuries of prejudice regarding Irish barbarism. There were particular conditions in place that allowed this counter-narrative emerge in the decades between 1740 and 1800 and the populous Irish population of the major London theatres of Covent Garden, Drury Lane and the Haymarket to flourish, onstage and offstage.

Michael Brown's Irish Enlightenment ends in failure with the bloody events of 1798 and the ensuing Union. But the regional London Irish theatrical Enlightenment did not fail in 1798. The eighteenth century had simply seen too much Irish success proliferating in the London playhouses, even for an event of this magnitude to knock it entirely off course. The multi-generational proliferation of heightened theatrical success from the 1740 s exceeded the

\footnotetext{
${ }^{68}$ For a fuller version of this argument, see O’Shaughnessy, 'Bit, by some mad whig'.
} 
capacity of domestic turbulence and bloodshed - and its representation in newspapers, parliamentary speeches, caricature and elsewhere - to return stage stereotypes to the pernicious Teague O'Divelly. This was not for the want of trying in some quarters: there were certainly efforts to make the link between 1641 and $1798 .{ }^{69}$ But the legacy of Clive, Woffington, Macklin and their peers lived on in the nineteenth century with O’Neill, Kenney, Sheridan Knowles and others. Oddly perhaps, the continuing success of the stage Irishman and Irishwoman, problematic in many ways, also points to the resilience of the eighteenthcentury's legacy into the nineteenth - there is no relapse to the bestial Irishman on stage, although the latter crops up in caricature and other forums. Rebellion and union did not conclude this regional strand of the Irish Enlightenment; it merely slowed it down for a time.

The emphasis of the first three essays in this volume is on performance. Although discussions of Stage Irishmen are manifold in assessments of eighteenth-century Irish theatre, Felicity Nussbaum makes a compelling argument that female actors are more agile and dynamic than thir male counterparts in their capacity to scrutinize stereotypes and power relations between Britain and Ireland. Her emphasis on cross-dressing in order to explore origins and social class illuminates how actresses such as Catherine Clive, Margaret Woffington and Maria Macklin embodied the unsettled relations across the Irish sea. Crucially, Nussbaum detects a growing assertiveness among these women as the century progresses, a confidence that chimes with the increasing volume of Irish patriotism over the period.

${ }^{69}$ See, for instance, a reprinting of John Temple 'as the most Effectual Warning-Piece to keep them upon their Guard against the Encroachments of Popery' about Catholic Emancipation in 1812 which includes an account of 1798. The Irish Rebellion: or, An History of the attempts of the Irish Papists to Extirpate the Protestants in the Kingdom of Ireland ... (London: Printed for J. Brindley, J. Hodges, and M. Cooper, 1812). 
This upbeat tone resonates with Jim Davis who assesses the career of John Johnstone, the quintessential Stage Irishman of the final quarter of the eighteenth century. For Davis, Johnstone's success was based on an adroit capacity to mediate Irishness in a manner alert both to the commercial demands of the London theatres and to the often febrile political backdrop of those years. Johnstone embodied tolerance and decency in an impressive swathe of roles that operated across the socio-economic spectrum, ensuring that Irishness was acceptable, even endearing to London audiences.

Oskar Cox Jensen is unconvinced. In his view, Johnstone's agency, not simply as an actor, but as a person, diminishes over his career. Johnstone's extraordinary popularity ensured that he was invoked in a proliferation of material and immaterial representations circulating in London. This is, Cox Jensen concedes, unremarkable in the burgeoning theatrical celebrity culture but, he argues, it takes on a special significance when the subject is seen to represent a nation. In the end, Johnstone is overwhelmed by stereotype, little more than an Irish 'dancing bear'. The differing views of Davis and Cox Jensen highlight the difficulty in deconstructing stereotypes and determining the parameters of success within a forum so enmeshed with other media, notably caricature, periodicals and song.

Thanks to the editorial efforts of John Greene, the work can begin proper on comparative studies of the Dublin and London theatres. ${ }^{70}$ Although the relationship between the two cities is present throughout the volume, three essays take it as their particular focus, showing how such work might add to our understanding of Georgian culture and politics.

Music's importance to the representation of Irish civilization is evident from Geoffrey Keating, Charles O'Conor and other cultural historians of the century: bards are perceived as keepers and embodiments of Gaelic culture, laws and history. When Goldsmith championed

${ }^{70}$ Theatre in Dublin 1745-1820: A Calendar of Performances, ed. John C. Greene, 6 vols. (Bethlehem: Lehigh University Press, 2011) 
Turlough O'Carolan 'the last Irish Bard', he recounts an anecdote of O'Carolan not only replaying a Vivaldi concerto he heard once but instantly capable of composing one in the same style; Irish culture then proves itself open to and capable of cultural synergies with European traditions in the spirit of the Enlightenment. ${ }^{71}$ Goldsmith was writing in 1760, at the moment, as Michael Burden shows us, the burletta was developing in London and Dublin. Burden's re-contextualization of the burletta's history, based on detailed research of the Dublin and London calendars of the 1750s and 1760s, impresses on us the creative energies between the two cities as well as marking the involvement of figures such as Isaac Bickerstaff and John O'Keeffe in musical innovation.

Dissatisfied with a full-blooded Irish patriot take on Richard Brinsley Sheridan, Robert Jones calls for a more nuanced approach. He brings to attention the multiple political allegiances of Sheridan - Irishman, Foxite Whig and MP for Staffordshire - in order to dissolve impossibly coherent perceptions of man and playwright. Taking as his focus a single word in Sheridan's great comedy, The School for Scandal, Jones not only reaffirms that trade remained at the forefront of Irish patriot issues, as it was for Molyneux at the end of the seventeenth century, but reminds us that Sheridan had duties and affiliations beyond Dublin or London that require further scholarly exploration. The mutability of personality that features in the play, argues Jones, shows how Sheridan worked through his Irish and English affiliations and has implications for how we understand other Irish writers negotiating these difficulties.

The ties that bind Dublin and London presented opportunity as well as difficulty. Colleen Taylor calls attention to Irish women playwrights of the late eighteenth and early nineteenth centuries, a cadre of writers, she points out, often overlooked due to Irish

\footnotetext{
${ }^{71}$ Oliver Goldsmith, 'The History of Carolan, the last Irish Bard' in The Collected Works of Oliver Goldsmith, ed. Arthur Friedman, 5 vols. (Oxford University Press, 1966), 3: 118.
} 
Romanticism's emphasis on female novelists. Taylor's careful reading of Sydney Owenson's The First Attempt (1807) and Alicia Sheridan Le Fanu's The Sons of Erin (1812) shows how politicized and Enlightened women could rewrite eighteenth-century theatrical tropes to refresh political discourse and make the case for female political agency. Glorvina's mantle (from The Wild Irish Girl) was a powerful political symbol in both Dublin and London.

The final quartet of essays in the volume explores how writers took historical and geographical approaches to teasing out political stances on identity, ethnicity and Enlightenment ideas. I continue my unabashed championing of Charles Macklin, taking as my subject his historical tragedy King Henry the VII (1746). Typically passed over in Macklin criticism, my reading of the play connects it to Addison's Cato and Irish theatrical antecedents to propose an alternative genealogy of eighteenth-century Irish theatre. Macklin's attempt to rewrite John Ford's Perkin Warbeck(1634), seen in this patriot context, thus bolsters his claim to be an Enlightenment figure.

Bridget Orr also argues for the importance of eighteenth-century historical tragedy, a too often neglected genre. Orr takes the case of Arthur Murphy's Alzuma (1773), his favourite of his serious plays and shows what a rich reading can be produced when one acknowledges Murphy's multiple allegiances - Irish, Catholic, and a pro-Bute propagandist in the 1760s when the play was written. Orr shows how Alzuma was shaped up — but did not ventriloquize - indigenous critiques of empire; Murphy's play is marked by a 'discourse of radical indigeneity' and provides a compelling argument for the further exploration of Murphy's serious plays - and indeed the eighteenth-century tragedy more generally.

James Field Stanfield will not be a name familiar to many, a point which underlines the importance of Declan McCormack's archival work on the northern circuit of English theatre. As already noted, the volume is heavily London-centric but McCormack shows the extraordinary stories that can be unearthed beyond the capital's environs: Stanfield's life and 
career-slaver, actor, abolitionist, writer — unfolds not only across northern England and Scotland but traverses the Atlantic as well. McCormack shows how Stanfield, traumatized by his past, used his theatrical success to fuel political and intellectual activism that established him as an important public reformer and a key participant in the 'Northern Enlightenment'. The chapter is a salutary reminder to theatre historians of the importance of looking beyond London and Dublin.

Helen Burke's essay on John O'Keeffe, the most successful Irish playwright in London in the 1780 s and 1790 s, considers his work in terms of vernacular cosmopolitanism, that is, a mode of cosmopolitanism produced by migrants who travel due to compulsion or necessity. Looking at four of his major works that invoke the pastoral, Burke reveals how O'Keeffe drew on his Irish Catholic heritage — marked by dispossession and disenfranchisement — to extrapolate a 'paradigmatic story of modernity itself'. What Burke shows is how O'Keeffe combines his concern for toleration and hospitality with his enthusiasm for London to 'expand the ethical horizons of his drama': like so many Irish theatrical practitioners and patriots before him, O'Keeffe sought to demonstrate how Irish culture and thought could enrich Britain; there was no conflict between his allegiances to the crown and shamrock.

Like my portrait of Macklin, the Irish theatrical Enlightenment in London sketched out in this introduction may appear largely idealized: there were, of course, many objections to pretensions of Irish civility and manifold episodes of racial discrimination. But for those Irish that made it — and theatre was a success story, in the main — we cannot underestimate the confidence that participation in vibrant London metropolitan life engendered. We now know that domestic Irish theatre was a rich and distinctive endeavour-the cover image of this volume is intended partly tongue and cheek — but it remainds the case, that for many in 
the theatrical professions, London was the goal. ${ }^{72}$ Ambition and achievement unified these people and there is a collective ebullient confidence that can be detected in their body of work and collaborations, energized by off stage Irish performative success and recognition, be it the wit of Laetitia Pilkington, the speeches of Sheridan, the conversational acumen of Burke, or the growth in Irish participation in institutional and club life in eighteenth-century London. The London theatres had a critical mass of Irish migrants who supported and fed off of each others' success. Enlightenment is concerned with individual and societal improvement, and the second half of the eighteenth century was critical to the dissemination of ideas of Irish Enlightenment in Britain by a group of remarkable people who operated increasingly with something of a swagger after 1745. The highpoint of this upbeat mood was the 1780 s - when Irish playwrights were particularly dominant and buoyed by the public success of their predecessors, especially Macklin and Goldsmith—-before the problems posed by the French Revolution and the United Irishmen intervened. Progression certainly stumbled then but by that stage, Irish civility had become a notion too entrenched to be toppled entirely. ${ }^{73}$

${ }^{72}$ See Helen Burke, Riotous Performances: The Struggle for Hegemony in the Irish Theater, 1712-1784 (University of Notre Dame Press, 2003).

${ }^{73}$ My thanks to Emily Anderson, Michael Griffin, Felicity Nussbaum and Gillian Russell for taking the time to read this introduction and offer so many helpful comments. 
Ireland, Enlightenment and the English Stage, 1740-1820 